\title{
Sustainability Reporting and Its Impact on Financial Performance: A Study of the Sri Lankan Financial Sector
}

\author{
P.O. De Silva \\ University of Uva Wellassa
}

\begin{abstract}
The sustainability reporting which integrates the organization's economic, environmental and social performance towards achieving better financial performance has become a contemporary issue due to the absence of a precise model or a rigid regulatory framework in this arena. Therefore, the purpose of this study is to identify whether there is a significant difference in sustainable disclosures among the financial institutes and how sustainability reporting influence on institutional performance. Accordingly, the author derived a disclosure index from the Global Reporting Initiative (GRI) guidelines which consist of 119 parameters to evaluate the content of the annual reports of listed banks and financial sector companies. Analysis provided a comparison between GRI guidelines and Generation four (G4) framework. Furthermore, the study investigated the causal relationship between the level of disclosures and financial performance. To serve this purpose, data was obtained from annual reports in the Security Exchange Commission (SEC), and companies' websites then analyzed quantitatively using SPSS 16 data analysis package.
\end{abstract}

The results of the study conclude that there's no significant difference in sustainability disclosures between listed banks and financial institutes and the number of disclosures has no significant influence on institutes' financial performance. Furthermore, the study confirmed that there's no significant

Corresponding Author:

P.O. De Silva, University of Uva Wellassa, E-mail:pethmidesilva@gmail.com 
difference between G4 framework disclosures (Adopted in 2016/2017 reporting period) and GRI guidelines (Adopted in 2017/2018 reporting period). Thereby, the study witnessed that businesses including financial institutes consume scarce resources, while paying poor attention in reporting their accountability towards the sustainability. Therefore, it needs recognizing sustainable responsibility.

\section{Keywords}

Corporate Disclosures; Financial Institutions; Financial Performance, Sustainability/Integrated Reporting

\section{Introduction}

The sustainability reporting is a voluntary endeavor which involves publishing accounts that reflect the economic, environment and social performance of an organization (Isenmann and Kim, 2006). The absence of a compulsory set of sustainability reporting rules and standards has caused variances in reporting practices among the companies. Consequently, it has influenced on business value creation process differently.

Moreover Sustainability, as a contemporary topic associated with the conservation of scarce resources, while upgrading the standard of living of the current generation, has raised a significant global concern (James, 2014). In the modern business era, it has become the rule of thumb in gaining a competitive advantage since it safeguards the business capacity in the value creation process. The integration of three dimensions; economic, environmental, and social uplifts the business' efficiency, effectiveness and transparency and leads businesses towards long-term success (Michael and Gross, 2004). So, integrated reporting which communicates combination and the role of each pillar in confirming the sustenance of the business processes are being endorsed across the globe (Albetairi, et al., 2018).

The Global Sustainability Standards Board features a modular, robust structure, and exemplifies the best practice for global reporting on a range of interrelated economic, environmental and social effects. GRI 101 (2016) recognizes the sustainability reporting standards (GRI Standards) as inspire firm accountability, manage risk, seize new opportunities, protect the environment, 
improve the society while thriving economy by improving governance, reputation, stakeholder relations, and building trust.

Usenko and Zenkina (2010) highlight the inability of financial performance measures in ascertaining the company's impact on the economy, environment, and society. Simply, the financial regulatory framework ignores the positivenegative environmental and societal externalities. It stimulates research on environmental, social, and sustainability reporting frameworks applicable to the financial sector. Importantly, by nature, the financial sector does not directly cause a negative impact on the environment and the society as it is involving inservice function (Nwobu, et al., 2017). However, the implications of banking operations with a diversified customer pool create demand for transparent disclosures for a broad range of stakeholders.

Likewise, the studies which examined sustainability reporting models adapted by the countries and the relationships between sustainability components and financial performance have questioned the true purpose of implementing sustainability reporting practices in the value creation process. Consequently, the commitments towards implementing voluntary reporting practices in a developing country like Sri Lanka can be influenced by the absence of a fixed model, recognized listing platform and the cost.

Therefore, the objective of this study is to examine the sustainability report content which integrates aforementioned three pillars and sustainability practices of the listed banks and finance companies that operate in the Colombo Stock Exchange, and to measure the association of level of disclosures with the firm performance i.e. Return on Assets (ROA) and Return on Equity (ROE) of banking and finance companies. Secondly, it overlooks the trends of integrated reporting comparing 2017 with 2016 level of disclosures in the banking sector.

\section{Literature Review}

Legitimacy Theory

Legitimacy is defined by Lindblom (1994) as the condition where the company's value system is compatible with the societal value system. This theory emphasizes the importance of meeting social expectations and standards to safeguard the long-term position. Align with the theory Faisal, et al., (2012) argues that sustainability reporting strengthens the firm's operative license in the society while reducing the risk. This explains the two-way relationships 
where the company stick to the social boundaries which are perceived as legitimate to gain the continual support from the society. (Khan, et al., 2013). However, the company has the discretion to operate within its institutionalized policies and constraints, but the failure to confirm the societal value of selfpractices may threaten the firms' survival (Oliver, 1991). Lindblom (1994) further claims as if there's a disparity between the company's actual value and the expected value the company's legitimacy may jeopardize resulting a legitimacy gap. Therefore, the communication of the true value to the society by adopting a globally accepted disclosure strategy is vital.

\section{Agency Theory}

The agency theory explains principal-agent relationships between internal, connected and external stakeholders (Ross, 1973). Agency conflict which arises due to information asymmetry destructs the smoothness of the relationship. An adequate level of sustainable disclosures bridges the gap between insiders and the outsiders (Shamil, et al., 2014; Dhaliwal, et al., 2011).

\section{Stakeholder Theory}

Freeman (1984) stipulates the stakeholder theory which endorses firm's accountability towards a range of stakeholders, i.e. suppliers, employees, community, environment etc. Harmoni (2013) explains that integrated reporting reinforces the firm's relationship with the society it operates.

\section{Hypotheses Development/Empirical Review}

The scope of literature covers the existing studies on the level of sustainability disclosures and the association between sustainability disclosures and the firm's performance.

Abeywardana and Panditharathna (2016) pinpoint that there's no consensus between the firms about the level of voluntary disclosures including economic/ social performance. An empirical study conducted in Malaysia analyzing sustainable disclosures of 15 commercial banks and revealed that social disclosures dominate the sustainability reporting framework (Harun, et al., 2013). The findings further explain banks tempt to disclose more on labor conditions and decent work. Yang and Yaacob (2012) describe that external pressure has promoted the level of social disclosures. Additionally, a survey conducted in the Mauritian banking industry using five disclosure indexes 
indicates human resource as the most favorite theme since it is the most important asset in the service industry (Ramdhony, 2015).

Moreover, the study of 12 commercial banks listed on the Dhaka Stock Exchange concludes that societal information is most extensively addressed with respect to the extent of financial reporting (Khan, et al., 2010). The scholars classify GRI requirements into 5 components as environmental, labor practices and decent work, product responsibility, human rights, and the society. However, society disclosures lead with $100 \%$ compared to $91.6 \%$ of labor practices and decent work disclosures.

In contrast, a survey conducted with 26 listed private banks in Dhaka Stock Exchange reveals that energy reduction, and greenhouse gas emission disclosures report $94.9 \%$ and $92.3 \%$ respectively (Akter, et al., 2017). The investigation of environmental disclosure trends via content analysis of annual reports published by 17 Ghana Stock Exchange Listed firms exposed that the level of disclosures are very low and they are strongly associated with the environmental sensitivity (Welbeck, et al., 2017).

Likewise, the inconsistencies in previous researches resulted in developing the following hypothesis.

H1 $\mathbf{a}$ : There is a significant difference in the level of sustainable disclosures between banks and financial institutions.

An empirical study performed covering thirty banks listed in Bangladesh Chittagong Stock Exchange (CSE) and Dhaka Stock Exchange (DSE) has presented a year on year (2011-2015) analysis emphasizing the yearly differences in sustainability reporting practices. According to that, disclosure levels are varying from year 2011 to 2015 (Mahmud, et al., 2019). Sobhan, et al. (2011) performed a trend analysis in two banks over ten years in Bangladesh, presented a significant increase in the level of disclosures over the period of 2000 to 2009. Moreover, content analysis conducted in a sample which comprised of 20 Malaysian financial institutes over the period of 2008-2011 reveals an improvement of information disclosures with the passage of time (Darus, et al., 2015).

As discussed above the studies which have been conducted over decades have been produced mixed results. Therefore, the following hypothesis is developed to analyze further. 
H2a: There is a significant difference between sustainable disclosures across the years.

Daub (2017) declares that the quality of sustainable reporting depends on the use of both qualitative and quantitative information, and on the level to which company succeeded economically along with the social and environmental efficiency and effectiveness. Therefore, a substantial number of researches have been conducted recently to determine the relationship between sustainability reporting and the firm's performance.

Most of the studies provided evidence for a significant positive relationship between sustainability reporting and firm performance. According to Baumunk (2009), the primary advantage of sustainable disclosures is boosting demand for the firm's products and services. Consequently, the rise of demand increases the firm's return. Furthermore, Preston and O'bannon, (1997) explained social responsibility disclosures create higher value for stakeholder and craft internal capabilities while minimizing cost which leads the firm towards better financial results.

A study performed in Jordanian Islamic banks obtaining data from 20082014 ascertains a statistically significant relationship between sustainability and financial measures such as; ROA and ROE (Zyadat, 2017). A field survey conducted with 60 Nigerian manufacturing companies listed in Nigerian Stock Exchange and registered in Corporate Affairs Commission, identifies a significant difference in performance between environmental responsible firms and irresponsible firms (Ngwakwe, 2010). So, it establishes a positive relationship between sustainability driven business practices and ROA. Similarly, a panel data regressions analysis performed by Yilmaz (2013) in Turkey banking industry finds a significant financial result with some social indicator disclosures. Jones (2005) develops an index score based on GRI to determine the relationship between sustainability disclosures and financial performance which is measured by financial ratios and market adjusted returns and found mixed positive outcomes with different measures.

A study in Greece identified that the banks which adhere to GRI guidelines and include sustainability indices outperform in the market due to their environmental and social performance and these guidelines have created demand for sustainability reporting in terms of environmental and social performance (Skouloudis, et al., 2011). 
All the studies that have been performed in relation to the impact of sustainable disclosure on financial performance haven't produced consistent results. There were some contrary evidences which shows no or negative relationships between variables. Aupperle, et al. (1985) analyzed the relationship between sustainability disclosures and profitability among the companies enlisted in Forbes and figure out no relationship between variables. Similarly, it was failed to establish a relationship between the amount of social, environmental disclosures and financial performance in the study conducted by Murray, et al. (2006) using the data in UK top 10 companies over 10 years period (1988-1997). Lopez, et al., (2007) divided 110 firms quoted in the Dow Jones Sustainability Index into two groups to determine the impact of sustainability on the performance and found a negative impact. Similarly, Buys, et al. (2011) investigated the economic performance of sustainability reporting using data from McGregor BFA database from 2002-2009 and found that there's no relationship between sustainability reporting and performance.

The aforementioned studies have been produced contradictory results. Thereby, the following hypothesis is developed to study further.

H3 $_{\mathbf{a}}$ : Level of sustainable disclosures (economic/ environmental and social disclosures) have an association with the banks' and financial institutes' financial performance.

\section{Sri Lankan Context}

Wijesinghe (2012) conducted a study in 75 companies which represent 14 industries to identify the current social responsibility reporting framework. GRI guidelines were used in this study and found a low level of disclosures in sustainability components including; governance, economy, environment, and society in Sri Lankan companies.

Dissanayake, et al., (2016) examined the relationship between sustainability reporting /sustainability key performance indicator (KPI) reporting and company-specific characteristics namely; company size, company age and financial performance using annual reports, sustainability reports and website contents of sixty public listed companies in Sri Lanka and found that company size as the most significant factor that effect on sustainability KPIs. In contrast to Wijesinghe (2012) large-scale corporations disclosed high level of disclosures to exploit performance benefits.

In-depth interviews conducted with eighteen top managers of subsidiaries by Beddewela \& Herzig (2013) seek out the reasons for the low level of social 
responsibility disclosures in the Sri Lankan context. According to that, institutionalized processes along with the internal legitimacy distract the companies from social reporting.

However, the literature is lacking on Sri Lankan finance sector. Therefore, the study fills the gap contributing to the literature by performing content analysis and considering the potential relationship between sustainability disclosures and the economic performance of listed banks and financial institutes in Sri Lanka.

\section{Methodology}

\section{Sampling and Data Collection}

The central bank of Sri Lanka provides a list of registered banks and financial institutes. The list is comprised of 26 local banks and 43 financial companies. However, out of this 69 companies, 2 are state-owned and only 11 banks and 28 finance companies are listed in the Colombo Stock Exchange, All Share Price Index. Among them, the study sample consists of 2 state-owned banks, 10 private banks, and 20 finance companies which are selected based on the accessibility to the financial statements with sustainability reports. Hence, the data employed in this study are sourced from the annual reports and sustainability reports of selected banks and financial companies. Furthermore, the study considers annual reports and sustainability reports issued by the banks (13 banks) over two years 2016-2017 and 2017-2018 reporting period, because the companies have been shifted from G4 framework (2016-2017 reporting period) to GRI framework (2017-2018 reporting period) during the period.

\section{Key Variables}

Author defined the variables considering the Sri Lankan context and they are listed below;

Figure 1: Conceptual Framework

\begin{tabular}{|c|c|}
\hline Economic Disclosures & $\begin{array}{c}\text { Financial } \\
\text { Performance } \\
\text { Environmental Disclosures } \\
\text { Return on Assets } \\
\text { Return on Equity }\end{array}$ \\
\hline Social Disclosures & \\
\hline
\end{tabular}




\section{Sustainability Reporting (SR) Index}

SR index score is derived from the consolidated set of GRI Sustainability Reporting Standards which is effective from 2018. Accordingly, 56 general standards, 13 economic standards, 23 environment standards, and 27 social standards are used. The total compilation of each component converts to $100 \%$ scale using the following formula;

$$
\text { Score }(s)=\frac{\text { Amount of compilation }(n)}{\text { Number of standards considered }} \times 100 \%
$$

However, the new set of standards is only applied in the sustainability reports published for 2017/2018 reporting period. Therefore, the alternative index is developed only for the banks based on previous reporting guidelines (G4 guidelines) to perform a comparative analysis between years 2017/2018 reporting period with 2016/2017 reporting period. (General 59 standards: = $\frac{n}{59} \times 100 \%$, Economic 13 standards: $s=\frac{n}{13} \times 100 \%$, Environment 26 standards: $s=\frac{n}{26} \times 100 \%$, Social 30 standards: $\left.s=\frac{n}{30} \times 100 \%\right)$.

\section{Return on Assets (ROA)}

ROA indicates the profitability of the firm relation to the total assets employed in the firm (Kabajeh, et al., 2012). It is widely used as a comparative measure because it substantially depends on the industry considered. It assesses how effective firm is in converting the amount invested in the assets through equity or debt financing into net income (Saragih, 2018). Consistent with the prior research (Garg, 2015; Griffin and Mahon, 1997; Zyada, 2017: Alshehhi, et al., 2018) ROA computes as;

$$
R O A=\frac{\text { net income }+ \text { interest expense }(P B T)}{\text { Average total assets }}
$$

\section{Return on Equity (ROE)}

ROE as a profitability ratio measures the amount of profits returned as a percentage of shareholders investments (Kabajeh, et al., 2012). It reveals the company's profit generation ability with the shareholder equity. ROE is a useful ratio in comparing company net income with the others in the industry. It illustrates the efficiency and effectiveness of the company turning money into 
gains for the investors (Saragih, 2018). Consistent with the prior research (Zyada, 2017; Alshehhi, et al., 2018) ROE computes as;

$$
R O E=\frac{\text { Net Income adjusted for tax }}{\text { Shareholder equity }}
$$

\section{Data Analysis}

Descriptive statistical analysis, independent sampling t-test, paired sampling ttest, correlation and regression analysis were performed to analyze the data collected on the aforementioned variables in order to conduct the analysis. Moreover, the Statistical Package for Social Sciences Version 16 (SPSS 16) is used to analyze the data.

\section{Findings and Analysis}

The degree of adherence to the global reporting initiatives of the banks and finance companies in 2017-2018 is shown in table 1.

Table 1: Application of GRI Guidelines (Reporting Period 2017-2018)

2017 - GRI Initiatives

$\begin{array}{llll}\text { General - 56 } & \text { Economic }- & \text { Environment } & \text { Social -27 } \\ \text { standards } & \text { 13 Standards } & -23 & \text { standards } \\ & & \text { Standards } & \end{array}$

\begin{tabular}{|c|c|c|c|c|c|c|}
\hline 这 & 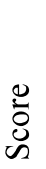 & 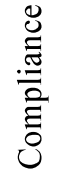 & 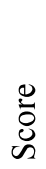 & 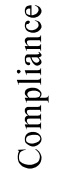 & 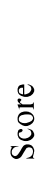 & 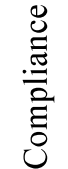 \\
\hline
\end{tabular}

\section{Banks}

$\begin{array}{lllllllll}\text { Commercial Bank } & 42 & 75 \% & 7 & 54 \% & 4 & 17 \% & 21 & 78 \% \\ \text { Peoples Bank } & 38 & 68 \% & 8 & 62 \% & 4 & 17 \% & 21 & 78 \% \\ \text { PABC } & 31 & 55 \% & 2 & 15 \% & 0 & 0 \% & 11 & 41 \% \\ \text { Amana } & 28 & 50 \% & 1 & 8 \% & 0 & 0 \% & 7 & 26 \% \\ \text { Sampath Bank } & 56 & 100 \% & 11 & 85 \% & 17 & 74 \% & 21 & 78 \% \\ \text { DFCC } & 33 & 59 \% & 3 & 23 \% & 0 & 0 \% & 6 & 22 \% \\ \text { HNB } & 52 & 93 \% & 6 & 46 \% & 3 & 13 \% & 8 & 30 \% \\ \text { MBSL } & 32 & 57 \% & 6 & 46 \% & 5 & 22 \% & 12 & 44 \% \\ \text { NSB } & 44 & 79 \% & 9 & 69 \% & 1 & 4 \% & 22 & 81 \%\end{array}$


SUSTAINABILITY REPORTING AND ITS IMPACT ON FINANCIAL PERFORMANCE: A STUDY OF THE

SRI LANKAN FINANCIAL SECTOR

NTB

Seylan Bank

BOC

Finance Companies

\begin{tabular}{|c|c|c|c|c|c|c|c|}
\hline 45 & $80 \%$ & 2 & $15 \%$ & 9 & $39 \%$ & 11 & $41 \%$ \\
\hline 45 & $80 \%$ & 9 & $69 \%$ & 22 & $96 \%$ & 27 & $100 \%$ \\
\hline 44 & $79 \%$ & 6 & $46 \%$ & 1 & $4 \%$ & 19 & $70 \%$ \\
\hline
\end{tabular}

AMW

Arpico Finance

Asia Asset

Asian Alliance

Associated Motors

Bimputh

CDB

Commercial Credit

LB Finance

LOLC

Peoples Leasing

Vallible Finance

Central Finance

BRAC Lanka Finance

Colombo Trust

Commercial Leasing

Orient Finance

Softlogic Finance

The Finance

Mercantile

Investments and

Finance PLC

$\begin{array}{llllllll}32 & 57 \% & 4 & 31 \% & 1 & 4 \% & 9 & 33 \% \\ 42 & 75 \% & 6 & 46 \% & 8 & 35 \% & 14 & 52 \% \\ 31 & 55 \% & 0 & 0 \% & 1 & 4 \% & 8 & 30 \% \\ 38 & 68 \% & 2 & 15 \% & 6 & 26 \% & 14 & 52 \% \\ 34 & 61 \% & 0 & 0 \% & 1 & 4 \% & 9 & 33 \% \\ 32 & 57 \% & 4 & 31 \% & 1 & 4 \% & 9 & 33 \% \\ 40 & 71 \% & 10 & 77 \% & 9 & 39 \% & 20 & 74 \% \\ 40 & 71 \% & 10 & 77 \% & 1 & 4 \% & 18 & 67 \% \\ 56 & 100 \% & 8 & 62 \% & 12 & 52 \% & 12 & 44 \% \\ 40 & 71 \% & 10 & 77 \% & 1 & 4 \% & 18 & 67 \% \\ 52 & 93 \% & 13 & 100 \% & 23 & 100 \% & 24 & 89 \% \\ 31 & 55 \% & 0 & 0 \% & 1 & 4 \% & 8 & 30 \% \\ 32 & 57 \% & 4 & 31 \% & 1 & 4 \% & 9 & 33 \% \\ 32 & 57 \% & 4 & 31 \% & 1 & 4 \% & 9 & 33 \% \\ 32 & 57 \% & 4 & 31 \% & 1 & 4 \% & 9 & 33 \% \\ 31 & 55 \% & 0 & 0 \% & 1 & 4 \% & 8 & 30 \% \\ 32 & 57 \% & 4 & 31 \% & 1 & 4 \% & 9 & 33 \% \\ 31 & 55 \% & 0 & 0 \% & 1 & 4 \% & 8 & 30 \% \\ 32 & 57 \% & 4 & 31 \% & 1 & 4 \% & 9 & 33 \% \\ 52 & 93 \% & 13 & 100 \% & 24 & 100 \% & 24 & 89 \%\end{array}$


The study presents that banks mostly report social indicators including terms and conditions of employment, manage employee relations, occupational health and safety, training and education, diversity, equal opportunities, nondiscrimination and compliance with the labor laws, which are associated with the employee well-being. Moreover, social disclosures cover interactions with local communities, ethical marketing, and labeling practices, supplier assessment.

Figure 2: Economic, Environmental and Social Performance of Banks

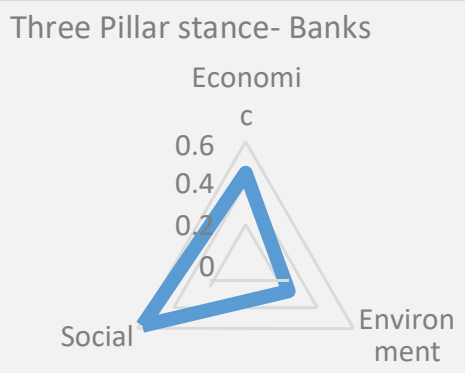

The economic disclosure stands behind the social disclosures. Even though banks disclose their direct economic impact and economic value it has failed to disclose the market presence, indirect economic impact, procurement practices, and anti-corruption policies.

Banks reporting on environmental disclosures are very poor. Banks are reluctant to disclose information on energy consumption, gas emission, effluents of waste, and supplier environmental assessment.

The study presents a similar trend in the financial companies, which discloses more on social performance but less on environmental performance.

Figure 3: Economic, Social, and Environmental performance of Finance Companies

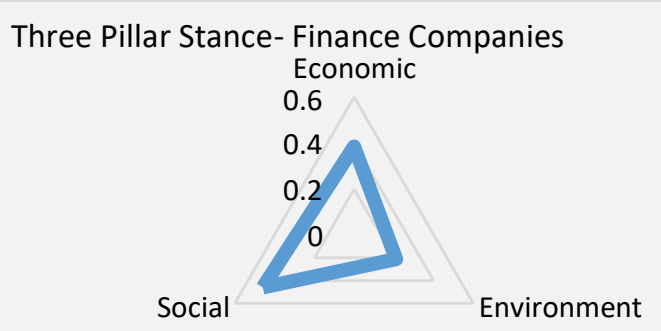


SUSTAINABILITY REPORTING AND ITS IMPACT ON FINANCIAL PERFORMANCE: A STUDY OF THE SRI LANKAN FINANCIAL SECTOR

Table 2: Application of G4 Guidelines (Reporting Period 2016-2017)

\begin{tabular}{|c|c|c|c|c|c|c|c|c|}
\hline \multicolumn{9}{|c|}{ 2016- G4 Standard system } \\
\hline & \multicolumn{2}{|c|}{$\begin{array}{c}\text { General - } 59 \\
\text { standards } \\
\end{array}$} & \multicolumn{2}{|c|}{$\begin{array}{c}\text { Economic - } 13 \\
\text { standards }\end{array}$} & \multicolumn{2}{|c|}{$\begin{array}{c}\text { Environment - } 26 \\
\text { standards }\end{array}$} & \multicolumn{2}{|c|}{$\begin{array}{l}\text { Social }-30 \\
\text { standards }\end{array}$} \\
\hline & 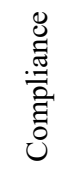 & 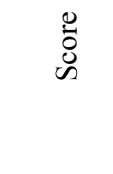 & 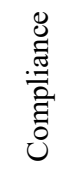 & 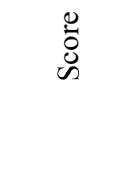 & 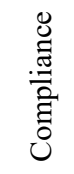 & $\begin{array}{l}0 \\
\stackrel{0}{0} \\
\mathscr{S}\end{array}$ & 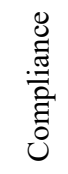 & $\begin{array}{l}0 \\
\stackrel{0}{0} \\
\text { Un }\end{array}$ \\
\hline $\begin{array}{l}\text { Commercial } \\
\text { Bank }\end{array}$ & 49 & 0.875 & 7 & 0.5384 & 3 & 0.1153 & 18 & 0.6 \\
\hline $\begin{array}{l}\text { Peoples } \\
\text { Bank }\end{array}$ & 45 & 0.8035 & 8 & 0.6153 & 2 & 0.0769 & 19 & 0.6333 \\
\hline PABC & 39 & 0.6964 & 3 & 0.2307 & 1 & 0.0384 & 11 & 0.3666 \\
\hline Amana & 30 & 0.5357 & 3 & 0.2307 & 1 & 0.0384 & 6 & 0.2 \\
\hline $\begin{array}{l}\text { Sampath } \\
\text { Bank }\end{array}$ & 57 & 1.0178 & 13 & 1 & 26 & 1 & 30 & 1 \\
\hline DFCC & 30 & 0.5357 & 3 & 0.2307 & 1 & 0.0384 & 8 & 0.2666 \\
\hline HNB & 31 & 0.5535 & 5 & 0.3846 & 7 & 0.2692 & 9 & 0.3 \\
\hline MBSL & 57 & 1.0178 & 9 & 0.6923 & 26 & 1 & 27 & 0.9 \\
\hline NSB & 52 & 0.9285 & 9 & 0.6923 & 2 & 0.0769 & 19 & 0.6333 \\
\hline NTB & 49 & 0.875 & 2 & 0.1538 & 10 & 0.3846 & 13 & 0.4333 \\
\hline Seylan Bank & 48 & 0.8571 & 13 & 1 & 26 & 1 & 30 & 1 \\
\hline $\mathrm{BOC}$ & 33 & 0.5892 & 3 & 0.2307 & 2 & 0.0769 & 20 & 0.6666 \\
\hline
\end{tabular}

Though aforementioned consolidated integrated reporting standards were introduced in 2016, it effectively practiced from 2018. Therefore, in the 20162017 reporting period companies applied G4 guidelines. Banks compliance with the G4 guidelines is presented above. Year on year analysis is performed in the banking sector since the reports are comprised of a large amount of disclosures.

The level of disclosures follows the similar pattern as 2017. Mostly bank discloses their social performance. Then economic performance and environmental disclosures stand at the last. 
Table 3: Descriptive Statistical Analysis of Level of Disclosures between Banks and Finance Companies

\begin{tabular}{llcccc}
\hline & \multicolumn{4}{c}{ Group Statistics } & \\
& Sector & $\mathrm{N}$ & Mean & $\begin{array}{c}\text { Std. } \\
\text { Deviation }\end{array}$ & $\begin{array}{c}\text { Std. Error } \\
\text { Mean }\end{array}$ \\
\hline \multirow{2}{*}{ Economic } & Banks & 12 & 44.8708 & 24.72908 & 7.13867 \\
& Finance Companies & 20 & 38.461 & 33.20287 & 7.42439 \\
& Banks & 12 & 23.9125 & 30.99327 & 8.94699 \\
Environmental & Finance Companies & 20 & 20.6535 & 30.67382 & 6.85887 \\
& Banks & 12 & 57.4075 & 26.16573 & 7.5534 \\
& Finance Companies & 20 & 45.9245 & 20.19436 & 4.5156 \\
\hline
\end{tabular}

Table 3 presents average level of economic, environmental and societal disclosures between banks and finance companies along with their deviation from the mean value.

Social disclosures of the banks reported the highest mean score of 57.41 ( $\sigma$ $=26.17)$. Similarly, finance companies also reported the highest mean score with the social disclosures $(\mu=45.92, \sigma=20.19)$. The mean scores of all three pillars indicate no significant difference between banks and finance companies.

Figure 4: Presentation of reporting practices differences in the box plot

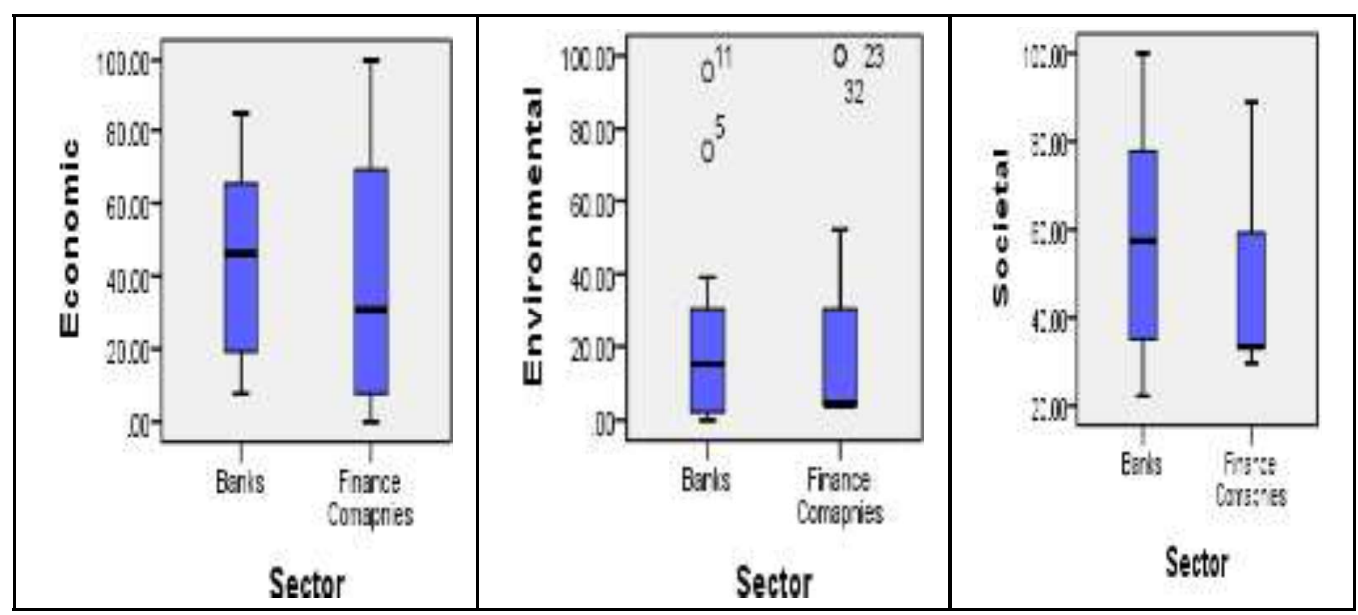


The box plot graphs endorse the descriptive statistical results. However, 2 banks and 2 finance companies (Sampath Bank, Seylan Bank, Peoples Leasing Finance Company and Mercantile Investment) present as outliers due to their level of environmental disclosures compared to others in the sector.

Independent Sample T-Test is performed to determine whether there is a statistically significant difference between banks and finance companies since it compares the mean values of two independent groups and determines whether the mean values are significantly different using statistical evidence. To perform the analysis banking sector economic, environmental and societal disclosure level (group 1) is compared with the finance companies economic, environmental and societal disclosure level (group 2) by developing a dichotomous scale indicating banks as 1 and otherwise as 0 .

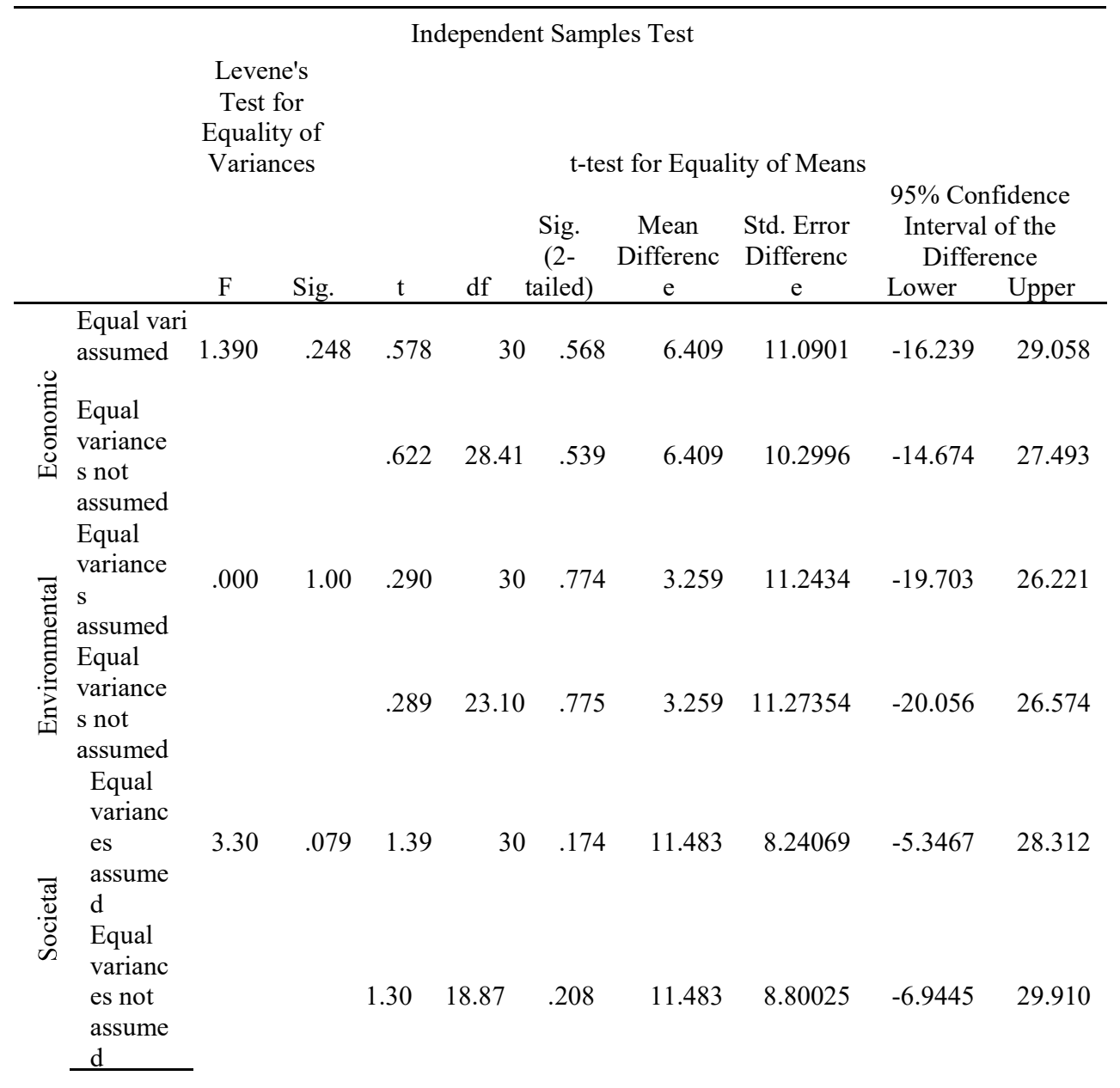


Levene's Test with a p-value of 0.248 for economic disclosures indicates that variances are equal across the two groups (Banks and Finance Companies). The $\mathrm{t}=0.578$ with a $\mathrm{p}$-value of $0.568(\mathrm{p}>0.05)$ deduce that there is no statistically significant difference in economic disclosures between banks and finance companies. Test results are similar to environmental and social disclosures. Levene's Test $p$ values of 1.000 and 0.079 confirm the assumption of equal variances are assumed. Then, the respective $t$ values 0.029 and 1.393 with p-values of 0.074 and 0.174 concludes that there's no statistically significant difference in the amount of environmental and social disclosures between banks and finance companies. Each variable 95\% Confidence Interval for mean values contain zeros; Economic -16.2392: 29.05890, Environmental 19.70310: 26.22110, and Social -5.34674: 28.31274, ratify that the results are not significant at the given significance levels.

Paired Sample T-Test results are analyzed to compare the banks' sustainability content between two years 2016/2017 and 2017/2018 (Table 04).

Table 4: Results of Paired Sample Correlation Analysis

\begin{tabular}{lllll}
\hline Paired Samples Correlations & $\mathrm{N}$ & Correlation & Sig. \\
& & & & \\
\hline Pair 1 & Economic 2017 and Economic 2016 & 12 & .882 & .000 \\
Pair 2 & Environmental 2017 and Environmental 2016 & 12 & .827 & .001 \\
Pair 3 & Social 2017 and Social 2016 & 12 & .784 & .003 \\
\hline
\end{tabular}

2017 economic, environmental, and social disclosures and 2016 economic, environmental, and social disclosures are statistically correlated with the respective $r$ values of $0.882,0.827$, and 0.784 ( $p$-values $0.000,0.001$, and $0.003)$. 
SUSTAINABILITY REPORTING AND ITS IMPACT ON FINANCIAL PERFORMANCE: A STUDY OF THE SRI LANKAN FINANCIAL SECTOR

Table 5: Results of Paired Sample t-Test

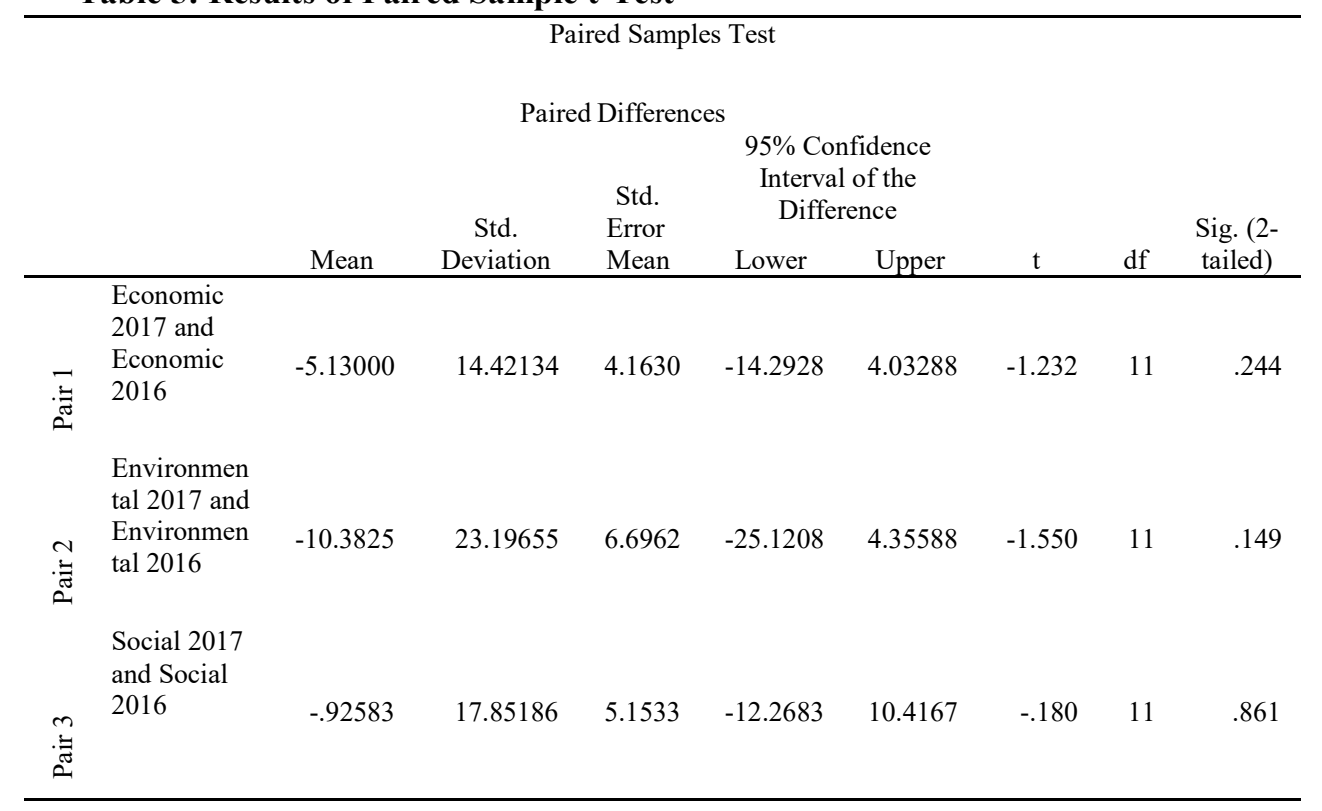

The economic disclosures $(t=-1.232, p>0.05)$ environmental disclosures $(t$ $=-1.550, p>0.05)$ social disclosures $(t=-.180, p>0.05)$ are not significantly differ between two years (Table 05).

Table 6 ascertains the relationship between the level of disclosures and the financial performance.

Table 6: Results of Pearson Correlation Analysis

\begin{tabular}{|c|c|c|c|c|c|}
\hline & & $\begin{array}{l}\bar{\sigma} \\
\bar{\Xi} \\
\bar{\Xi} \\
0\end{array}$ & 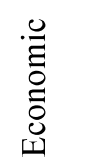 & 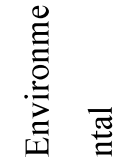 & $\begin{array}{l}\bar{\pi} \\
. \frac{\pi}{0} \\
0 \\
\ddot{n}\end{array}$ \\
\hline \multirow[t]{3}{*}{ ROE } & Pearson Correlation & .240 & .141 & -.061 & .137 \\
\hline & Sig. (2-tailed) & .185 & .442 & .741 & .454 \\
\hline & $\mathrm{N}$ & 32 & 32 & 32 & 32 \\
\hline \multirow[t]{3}{*}{ ROA } & Pearson Correlation & -.010 & .015 & -.034 & -.135 \\
\hline & Sig. (2-tailed) & .955 & .935 & .854 & .463 \\
\hline & $\mathrm{N}$ & 32 & 32 & 32 & 32 \\
\hline
\end{tabular}

**. Correlation is significant at the 0.01 level (2-tailed). 
Economic disclosures with ROE / ROA results p-value of 0.185 and 0.442 respectively, which indicate that the level of disclosures does not statistically influence on the performance. Likewise, the degrees of environmental and social disclosures do not significantly influence financial measures; ROA and ROE with respective p- Values of 0.741 and 0.454 .

Table 7: Results of Linear Regression Analysis

\begin{tabular}{|c|c|c|c|c|c|c|}
\hline \multirow{2}{*}{\multicolumn{2}{|c|}{ Model }} & $\begin{array}{c}\text { ANOV } \\
\mathrm{A}^{\mathrm{a}}\end{array}$ & & & \multirow{3}{*}{$\frac{\mathrm{F}}{.750}$} & \multirow{3}{*}{$\begin{array}{l}\text { Sig. } \\
.531^{\mathrm{b}}\end{array}$} \\
\hline & & \multirow{2}{*}{$\frac{\text { Sum of Squares }}{2.900}$} & \multirow{2}{*}{$\frac{\mathrm{df}}{3}$} & \multirow{2}{*}{$\begin{array}{r}\text { Mean Square } \\
.967\end{array}$} & & \\
\hline 1 & Regression & & & & & \\
\hline & Residual & 36.073 & 28 & 1.288 & & \\
\hline & Total & 38.973 & 31 & & & \\
\hline
\end{tabular}

a. Dependent Variable: ROA

b. Predictors: (Constant), Societal, Environmental, Economic

\begin{tabular}{|c|c|c|c|c|c|c|}
\hline \multicolumn{2}{|c|}{ Model } & Sum of Squares & $\mathrm{df}$ & Mean Square & $\mathrm{F}$ & Sig. \\
\hline \multirow[t]{3}{*}{1} & Regression & 140.787 & 3 & 46.929 & .750 & $.531^{\mathrm{b}}$ \\
\hline & Residual & 1751.283 & 28 & 62.546 & & \\
\hline & Total & 1892.071 & 31 & & & \\
\hline
\end{tabular}

a. Dependent Variable: ROE

b. Predictors: (Constant), Societal, Environmental, Economic

The regression model developed to measure the association of level of general, social, environmental, and social disclosures fails to ascertain a relationship with the financial measures (ROA and ROE) with $p$ values of 0.531 and 0.531 (Table 07).

\section{Discussion}

Majority of the banks and finance companies in Sri Lanka adhere to the Consolidated GRI Sustainability Reporting Standards issued by the Global Sustainability Standards Board (GSSB). Sustainability reporting practices are concentrated on the social disclosures rather environmental risk disclosures. Similar results have been observed in Malaysian Banking sector by Harun, et al. (2013). The issues bothering on employee/ community investment such as training and development, equal opportunities, defined benefit plans, employee 
health and safety and interactions with the local community has gained more attention in terms of sustainability disclosures (Khan, et al., 2010; Nwobu, et al.,2017). The precedent statement reflects the poor understanding of environmental risk associated with contemporary environmental issues such as global warming, climate change, waste disposal etc. Therefore, Sri Lankan banking and finance sector disclosures are inconsistent with the disclosures produced by Dhaka Stock Exchange-listed banks (Akter, et al., 2017).

The comparative analysis of two level of disclosures; G4 standards and GRI standards over two years period 2016/2017 and 2017/2018 shows no improvement over the period. 2016/2017 level of disclosures is equal to the 2017/2018 level of disclosures. Therefore, the findings of the study do not agree with the Mahmud, et al., (2019; Garg, (2015); Sobhan, et al., (2011).

Because of the growing interest in reporting economic, social, and environmental performance, the study is concerned with measuring the relationship between sustainability disclosures and financial performance. It concludes that the level of disclosures has no correlation or association with the financial performance measure. Aupperle, et al., (1985) report the similar results in a study of firms listed in the Forbes. Investigation of UK top 10 companies over 1988-1997 period fail to ascertain a relationship between the variables since $\mathrm{p}$-value $>0.05$.

\section{Conclusion}

The study aims to discover the pattern of sustainability disclosure practices of companies in the financial sector in Sri Lanka. The results elucidate that financial companies are more interested in social disclosures than disclosing indirect economic impact and environmental performance. Moreover, the study confirms that there is no improvement in the level of disclosures over the period of time. In addition, the analysis reveals sustainability disclosures of a firm create no impact on the Return on Equity and Return on Assets. Therefore, the findings resulted in rejection of the hypotheses developed.

\section{Implications}

Regulators continuous monitoring of sustainability disclosure practices is required to maintain a balance between each layer/pillar. Besides, banks and financial institutes require self-governance in order to contribute towards social, economic and environmental performance. Reporting on sustainability does not 
provide immediate benefits, but enhanced transparency, reduced risk, increased stakeholder involvement will produce benefits in the long-run.

This paper provides inference for future studies. Future scholars can determine causes for sustainability reporting while analyzing the disclosures over the extended period. Additionally, cross-sectional analysis across the different industries can be performed by identifying challenges encountered by banks in reporting social, economic and environmental performance.

\section{References}

Abeywardana, N. L. E. \& Panditharathna, K. M., 2016. The extent and determinants of voluntary disclosures in annual reports: evidence from banking and finance companies in Sri Lanka. Accounting and Finance Research, 5(4), p. 147-162.

Akter, N., Siddik, A. B. \& Mondal, S. A., 2017. Sustainability Reporting on Green Financing: A Study of Listed Private Commercial Banks in Bangladesh. Journal of Business and Technology (Dhaka), 12(2), pp. 14-28.

Yilmaz, I., 2013. Social Performance vs. Financial Performance: CSR disclosures as an indicator of Social Performance. International Journal of Finance \& Banking Studies, 2(2), pp. 56-65.

Zyada, A. A. H., 2017. The Impact of Sustainability on the Financial Performance of Jordanian Islamic Banks. International Journal of Economics and Finance, 9(1), pp. 55-63.

Albetairi, H. T. A., Kukreja, G. \& Hamdan, A., 2018. Integrtaed Reporting and Financial Performance: Empirical Evidences from Baharaini Listed Insurance Companies. Accounting and Finance Research, 7(3), pp. 102110.

Alshehhi, A., Nobanee, H. \& Khare, N., 2018. The Impact of Sustainability Practices on Corporate Financial Performance: Literature Trends and Future Research Potential. Sustainability, Volume 10.

Aupperle, K. E., Carroll, A. B. \& Hatfield, J. D., 1985. An Empirical Examination of the Relationship between Corporate Social Responsibility and Profitability. he Academy of Management Journal, 28(2), pp. 446-463. 
Baumunk, J. A., 2009. Sustainability reporting and XBRL.

Buys, P., Oberholzer, M. \& Andrikopoulos, P., 2011. An Investigation of the Economic Performance of Sustainability Reporting Companies Versus NonReporting Companies: A South African Perspective. Journal of Social Science, 29(2), pp. 151-158.

Darus, F., Mad, S. \& Nejati, M., 2015. Ethical and Social Responsibility of Financial Institutions: Influence of Internal and External Pressure. Procedia Economics and Finance, Volume 28, p. 183 - 189.

Daub, C. H., 2017. Assessing the Quality of Sustainability Reporting: An Alternative Methodological Approach. Journal of Cleaner Production, 15(1), pp. 75-85.

Dhaliwal, D. S., Li, O. Z. \& Tsang, A., 2011. Voluntary non-financial disclosure and the cost of equity capital: The initiation of corporate social responsibility reporting. The Accounting Review, 86(1), pp. 59-100.

Dissanayake, D., Tilt, C. \& Xydias-Lobo, M., 2016. Sustainability Reporting by Publicly Listed Companies in Sri Lanka. Journal of Cleaner Production, Volume 129, pp. 169-182.

Faisal, F., Tower, G. \& Rusmin, R., 2012. Legitimising Corporate Sustainability Reporting Throughout the World Journal. Australasian Accounting, Business and Finance Journal, 6(2), pp. 19-34.

Freeman, R. E., 1984. Strategic Management: A Stakeholder Approach. London: Financial Times Prentice Hall.

Garg, P., 2015. Impact of Sustainabilty Reporting on Firm Perfromance of Companies in India. International Journal of Marketing and Business Communication, 4(3), pp. 38-45.

Global Sustainability Standards Board (GSSB), 2016. GRI 101 Foundation. Amsterdem

Griffin, J. J. \& Mahon, J. F., 1997. The Corporate Social Performance and Corporate Financial Debate: Twenty-Five Years of Incomparable Research. Business Society, 36(1), pp. 5-31.

Harmoni , A., 2013. Stakeholder-Based Analysis of Sustainability Report: A Case Study on Mining Companies in Indonesia. 
Harun, A., Rashid, A. A. \& Alrazi, B., 2013. Measuring the quality of sustainability disclosure among the Malaysian commercial banks. World Applied Sciences Journal, 28(13), pp. 195-201.

James, M. L., 2014. The Benefits of sustainability and Integrated Reporting: An investigation of Accounting Major's Perception. Journal of Legal, Ethical and Regulatory Issues, 17(2), pp. 93-113.

Jones, S., 2005. Notes of the University of Sydney Pacioli Society: Sustainability reporting in Australia: An empirical overview. Abacus, Volume 41, pp. 211-216.

Kabajeh, M. A. M., Nu'aimat, S. M. A. \& Dahmash, F. N., 2012. The Relationship between the ROA, ROE and ROI Ratios with Jordanian Insurance Public Companies Market Share Prices. International Journal of Humanities and Social Science, 2(11), pp. 115-120.

Khan, A., Muttakin, M. B. \& Siddiqui, J., 2013. Corporate Governance and Corporate Social Responsibility Disclosures: Evidence from an Emerging Economy. Journal of Business Ethics, 114(2), pp. 270-223.

Khan, H.-U.-Z., Islam, M. A., Fatima , J. K. \& Ahmed, K., 2010. Corporate sustainability reporting of major commercial banks in line with GRI: Bangladesh evidence. International Journal of Law and Management, 52(2), pp. 82-109.

Lindblom, C. K., 1993. The Implication of Organization Legitimacy for Corporate Social Performance and Disclosure. New York

Lopez, M. V., Garcia, A. \& Rodriguez, L., 2007. Sustainable Development and Corporate Performance: A Study Based on the Dow Jones Sustainability Index. Journal of Business Ethics, Volume 75, pp. 285-300.

Mahmud, S., Biswas, T. \& Islam, N., 2019. Sustainability Reporting Practices and Implications of Banking Sector of Bangladesh according to Global Reporting Initiative (GRI) Reporting Framework: An Empirical Evaluation. International Journal of Business and Management Invention, 6(3), pp. 114.

Michael, B. \& Gross, R., 2004. Running Business Like a Government in The New Economy Lessons for Organizational Design and Corporate Governance. Corporate Governance, 4(3), pp. 32-46.

Murray, A., Sinclair, D., Power, D. \& Gray, R., 2006. Do Financial Markets Care About Social And Environmental Disclosure? Further evidence and 
exploration from the UK. Accounting, Auditing \& Accountability Journal, 19(2), pp. 228-255.

Ngwakwe, C. C., 2010. Environmental Responsibility and Firm Performance: Evidence from Nigeria. International Journal of Economics and Management Engineering, 2(10), pp. 1055-1062.

Nwobu, O. A., Owolabi, A. \& Iyoha, F. O., 2017. Sustainability Reporting in Financial Institutions: A Study of The Nigerian Banking Sector. Journal of Internet Banking and Commerce, 22(S8).

Oliver, C., 1991. Strategic responses to institutional processes. Academy of Management Review, 16(1), pp. 145-179.

Preston, L. E. \& O'bannon, D. P., 1997. The corporate social-financial performance relationship: A typology and analysis. Business Society, 36(4), pp. 419-429.

Ramdhony, D., 2015. Corporate Social Reporting by Mauritian Banks. International Journal of Accounting and Financial Reporting, 5(2), pp. 2162-3082.

Ross, S.,1973. The economic theory of agency: The principal's problem. American Economic Review, 63(2), pp. 134-139.

Saragih, J. L., 2018. The Effects of Return on Assets (ROA), Return on Equity (ROE), and Debt to Equity Ratio (DER) on Stock Returns in Wholesale and Retail Trade Companies Listed in Indonesia Stock Exchange. International Journal of Science and Research Methodology, 8(3), pp. 348-367.

Shamil , M. M., Shaikh, J. M., Ho, P. \& Krishnan, A., 2014. The influence of board characteristics on sustainability reporting: Empirical evidence from Sri Lankan firms. Asian Review of Accounting, 22(2), pp. 78-97.

Skouloudis, A., Evangelinos, K., Nikolaou, I. \& Filho, W. L., 2011. An overview of corporate social responsibility in Greece: perceptions, developments and barriers to overcome. Business Ethics: A European Review, 20(2), pp. 205-226.

Sobhan, F. A., Zainuddin, Y., Amran, A. \& Baten, A., 2011. Corporate sustainability disclosure practices of selected banks: A trend analysis approach. African Journal of Business Management, 5(7), pp. 2794-2804. 
Usenko, L. \& Zenkina, I., 2010. Modern Trends and Issues of Corporate Reporting Data Disclosures on Organization Activities. Mediterranean Journal of Science, Volume 7, pp. 212-220.

Welbeck, E. E., Owusu, G. M. Y., Bekoe, R. A. \& Kusi, J. A., 2017. Determinants of environmental disclosures of listed firms in Ghana. International Journal of Corporate Social Responsibility, pp. 2-11.

Zyadat, A. A. H., 2017. The Impact of Sustainability on the Financial Performance of Jordanian Islamic Banks. International Journal of Economics and Finance, 9(1), pp. 55-63. 
SUSTAINABILITY REPORTING AND ITS IMPACT ON FINANCIAL PERFORMANCE: A STUDY OF THE SRI LANKAN FINANCIAL SECTOR

\section{Appendix A}

\begin{tabular}{|c|c|c|}
\hline \multicolumn{2}{|c|}{ Disclosure Index } & \\
\hline \multicolumn{2}{|c|}{\begin{tabular}{|l|l} 
G4 Guidelines & GRI Guidelines \\
\end{tabular}} & \\
\hline \multicolumn{2}{|c|}{ General Disclosures } & \\
\hline G4-3 & $102-1$ & Name of the organization \\
\hline 4 & $102-2$ & Activities, brands, products and services \\
\hline 5 & $102-3$ & Location of headquarters \\
\hline 6 & $102-4$ & Location of operations \\
\hline 7 & $102-5$ & Ownership and legal form \\
\hline 8 & $102-6$ & Markets served \\
\hline 9 & $102-7$ & Scale of the organization \\
\hline $10 \mathrm{n} 11$ & $102-8$ & Information on employees and other workers \\
\hline 12 & $102-9$ & Supply chain \\
\hline 13 & $102-10$ & Significant changes to the organisation and its supply chain \\
\hline 14 & $102-11$ & Precautionary Approach \\
\hline 15 & $102-12$ & External initiatives \\
\hline 16 & $102-13$ & Membership of associations \\
\hline 1 & $102-14$ & Statement from senior decision-maker \\
\hline 2 & $102-15$ & Key impacts, risks, and opportunities \\
\hline 56 & $102-16$ & Values, principles, standards, and norms of behavior \\
\hline 57 & $102-17$ & Mechanisms for advice and concerns about ethics \\
\hline 58 & & $\begin{array}{l}\text { Internal and external mechanisms for reporting concerns about unethical or unlawful behaviour } \\
\text { and matters related to organisation's integrity including whistle-blowing mechanisms or hotlines }\end{array}$ \\
\hline Governance 34 & $102-18$ & Governance structure \\
\hline 35 & $102-19$ & Delegating authority \\
\hline 36 & $102-20$ & Executive-level responsibility for economics, environmental and social topics \\
\hline 37 & $102-21$ & Consulting stakeholders on economic, environmental and social topics \\
\hline 38 & $102-22$ & Composition of the highest governance body and its committees \\
\hline 39 & $102-23$ & Chair of the highest governance body \\
\hline 40 & $102-24$ & Nominating and selecting the highest governance body \\
\hline 41 & $102-25$ & Conflicts of interest \\
\hline 42 & $102-26$ & $\begin{array}{l}\text { Role of highest governance body in setting purpose, values and strategy } \\
\text { purpose, values and strategy }\end{array}$ \\
\hline 43 & $102-27$ & $\begin{array}{l}\text { Measures taken to develop and enhance the collective knowledge of the highest governing body } \\
\text { on economic, environmental and social topics }\end{array}$ \\
\hline 44 & $102-28$ & $\begin{array}{l}\text { Processes and actions taken in response to evaluation of the performance of the highest } \\
\text { governance body's in respect to governance of performance economic, environmental and social } \\
\text { topics }\end{array}$ \\
\hline 45 & $102-29$ & Identifying and managing economic, environmental, and social impacts \\
\hline 46 & $102-30$ & Effectiveness of risk management processes \\
\hline 47 & $102-31$ & Review of economic, environmental, and social topics \\
\hline 48 & $102-32$ & Highest governance body's role in sustainability reporting \\
\hline 49 & $102-33$ & Communicating critical concerns \\
\hline 50 & $102-34$ & Nature and total number of critical concerns \\
\hline 51 & $102-35$ & Remuneration policies \\
\hline 52 & $102-36$ & Process for determining remuneration \\
\hline 53 & $102-37$ & Stakeholders' involvement in remuneration \\
\hline 54 & $102-38$ & Annual total compensation ratio of highest paid individual \\
\hline 55 & $102-39$ & Percentage increase in annual total compensation ratio of highest paid individual \\
\hline 24 & $102-40$ & List of stakeholder groups \\
\hline & $102-41$ & Collective bargaining agreements \\
\hline 25 & $102-42$ & Identifying and selecting stakeholders \\
\hline 26 & $102-43$ & Approach to stakeholder engagement \\
\hline 27 & $102-44$ & Key topics and concerns raised \\
\hline 17 & $102-45$ & Entities included in the consolidated financial statements \\
\hline 18 & $102-46$ & Defining report content and topic boundaries \\
\hline
\end{tabular}




\begin{tabular}{|c|c|c|}
\hline & \multirow{2}{*}{\begin{tabular}{l|l|}
19 & $102-47$ \\
20 &
\end{tabular}} & \multirow{2}{*}{\begin{tabular}{|l|} 
List of material topics \\
Material Aspect boundaries within the organization
\end{tabular}} \\
\hline 20 & & \\
\hline 21 & & Material Aspect boundaries outside the organization \\
\hline 22 & $102-48$ & Restatements of information \\
\hline 23 & $102-49$ & Changes in reporting \\
\hline ReportingCycle & $102-50$ & Reporting period \\
\hline 29 & $102-51$ & Date of most recent report \\
\hline 30 & $102-52$ & Reporting cycle \\
\hline 31 & $102-53$ & Contact point for questions regarding the report \\
\hline & $102-54$ & Claims of reporting in accordance with the GRI Standards \\
\hline 32 & $102-55$ & GRI content index \\
\hline 33 & $102-56$ & External assurance \\
\hline \multicolumn{3}{|c|}{ Economic Disclosures } \\
\hline EC 1 & $201-1$ & Direct economic value generated and distributed \\
\hline EC 2 & $201-2$ & Financial implications and other risks and opportunities due to climate change \\
\hline EC 3 & $201-3$ & Defined benefit plan obligations and other retirement plans \\
\hline EC 4 & $201-4$ & Financial assistance received from government \\
\hline EC 5 & $202-1$ & Ratios of standard entry level wage by gender compared to local minimum wage \\
\hline EC 6 & $202-2$ & Proportion of senior management hired from the local community \\
\hline EC7- I0irectEc & $203-1$ & Development of infrastructure and service supported \\
\hline EC8 & $203-2$ & Significant indirect economic impacts \\
\hline EC 9 & $204-1$ & Proportion of spending on local suppliers \\
\hline \multirow[t]{2}{*}{ SO 3} & $205-1$ & Operations assessed for risks related to corruption \\
\hline & $205-2$ & Communication and training on anti-coruption policies and procedures \\
\hline \multirow[t]{2}{*}{ SO 5} & $205-3$ & Confirmed incidents of corruption and actions taken \\
\hline & $206-1$ & Legal action for anti competitive behaviour, anti trust and monopoly practices \\
\hline \multicolumn{3}{|c|}{ Environmnetal Disclosure } \\
\hline EN 1 & $301-1$ & Materials used by weight or volume \\
\hline EN 2 & & Percentage of materials used that are recycled input materials \\
\hline EN 3 & $302-1$ & Energy consumption within the organization \\
\hline EN 4 & $302-2$ & Energy consumption outside the organization \\
\hline EN 5 & $302-3$ & Energy intensity \\
\hline EN 6 & $302-4$ & Reduction of energy consumption \\
\hline \multirow[t]{5}{*}{ EN 7/ EN 27} & $302-5$ & Mitigation of environment impact of product and service \\
\hline & $304-1$ & $\begin{array}{l}\text { Operational sites owned, leased, managed in or adjacent to, protected areas and areas of high } \\
\text { biodiversity value outside protected areas }\end{array}$ \\
\hline & $304-2$ & Significant impacts of activities, products and services on biodiversity \\
\hline & $304-3$ & Habitats protected or restored \\
\hline & $304-4$ & $\begin{array}{l}\text { IUCN Red List species and national conservation list species with habitats in areas affected by } \\
\text { operations }\end{array}$ \\
\hline EN 15 & $305-1$ & Direct (Scope 1) GHG emissions \\
\hline EN 16 & $305-2$ & Energy indirect (Scope 2) GHG emissions \\
\hline EN 17 & $305-3$ & Other indirect (Scope 3) GHG emissions \\
\hline EN 18 & $305-4$ & GHG emissions intensity \\
\hline EN 19 & $305-5$ & Reduction of GHG emissions \\
\hline EN 20 & $305-6$ & Emissions of ozone-depleting substances (ODS) \\
\hline EN 21 & $305-7$ & Nitrogen oxides (NOx), sulphur oxides ( $\mathrm{SOx}$ ) and other significant air emissions \\
\hline EN 22 & $306-1$ & Water discharge by quality and destination \\
\hline EN8 & $306-2$ & Waste by type and disposal method \\
\hline EN 10 & & Percentage and total volume of water recycled and reused \\
\hline EN 25 & $306-4$ & Transport of hazardous waste \\
\hline EN 9 & $306-5$ & Water bodies affected by water discharges and/ or runoff \\
\hline EN 31 & & Total environmental protection expenditures and investments by type \\
\hline EN 32 & $308-1$ & New suppliers that were screened using environmental criteria \\
\hline EN 34 & & $\begin{array}{l}\text { Number of grievances about environmental impacts filed, addressed and resolved through formal } \\
\text { grievance mechanisms }\end{array}$ \\
\hline
\end{tabular}


SUSTAINABILITY REPORTING AND ITS IMPACT ON FINANCIAL PERFORMANCE: A STUDY OF THE SRI LANKAN FINANCIAL SECTOR

\begin{tabular}{|c|c|c|}
\hline \multicolumn{2}{|c|}{ Socieatal Disclosures } & \multirow[b]{2}{*}{ New employee hires and employee turnover } \\
\hline LA 1 & $401-1$ & \\
\hline LA2 & $401-2$ & $\begin{array}{l}\text { Benefits provided to full-time employees that are not provided to temporary or part-time } \\
\text { employees }\end{array}$ \\
\hline LA 3 & $401-3$ & Parental leave \\
\hline LA 4 & $402-1$ & Minimum notice periods regarding operational changes \\
\hline LA 5 & $403-1$ & Workers representation in formal joint management-worker health and safety committees \\
\hline LA 6 & $403-2$ & $\begin{array}{l}\text { Types of injury and rates of injury, occupational diseases, lost days and absenteeism, and } \\
\text { number of work-related fatalities }\end{array}$ \\
\hline LA 7 & $403-3$ & Workers with high incidence or high risk of diseases related to their occupation \\
\hline LA 8 & $403-4$ & Health and safety topics covered in formal agreements with trade unions \\
\hline LA 9 & $404-1$ & Average hours of training per year per employee \\
\hline LA 10 & $404-2$ & Programs for upgrading employee skills and transition assistance programs \\
\hline LA 11 & $404-3$ & Percentage of employees receiving regular performance and career development reviews \\
\hline LA 12 & $4051-1$ & Diversity of governance bodies and employees \\
\hline LA 13 & $405-2$ & Ratio of basic salary and remuneration of women to men \\
\hline LA 16 & & $\begin{array}{l}\text { Number of grievances about labour practices filed, addressed and resolved through formal } \\
\text { grievance mechanisms }\end{array}$ \\
\hline HR3 & $406-1$ & Incidents of discrimination and corrective actions taken \\
\hline HR4 & $407-1$ & $\begin{array}{l}\text { Operations and suppliers in which the right to freedom of association and collective bargaining } \\
\text { maybe at risk }\end{array}$ \\
\hline HR 5 & $408-1$ & Operations and suppliers at significant risk for incidents of child labour \\
\hline HR6 & $409-1$ & Operations and suppliers at significant risk for incidents of forced or compulsory labour \\
\hline SO 1 & $413-1$ & Operations with local community engagement, impact assessments, and development programs \\
\hline $\mathrm{SO} 2$ & $413-2$ & Operations with significant actual or potential negative impact on local communities \\
\hline SO 10 & $414-1$ & New suppliers that were screened using social criteria \\
\hline PR 1 & $416-1$ & Assessment of the health and safety impacts of product and service categories \\
\hline PR 2 & $416-2$ & Incidents of non-compliance concerning the health and safety impacts of products and services \\
\hline PR3 & $417-1$ & Requirements for product and service information and labelling \\
\hline PR4 & $417-2$ & Incidents of non-compliance concerning product and service information and labelling \\
\hline PR 6 & & Sale of banned or disputed products \\
\hline PR7 & $417-3$ & Incidents of non-compliance concerning marketing communications \\
\hline PR5 & & Results of surveys measuring customer satisfaction \\
\hline PR8 & $418-1$ & Substantiated complaints concerning breaches of customer privacy and losses of customer data \\
\hline PR 9 & $419-1$ & Non-compliance with laws and regulations in the social and economic area \\
\hline
\end{tabular}

